\title{
Comparison of Estrous Performance and Progesterone Level of Kacang Goats Induced by PGF2a Versus Ovsynch Protocol
}

\author{
Budianto Panjaitan ${ }^{1}$, Almira Dewi ${ }^{2}$, Fadli FR Nasution ${ }^{2}$, Mulyadi Adam ${ }^{3}$, Tongku N. Siregar ${ }^{4}$, Cut N. Thasmi ${ }^{4}$, and \\ Syafruddin Syafruddin ${ }^{1}$ \\ ${ }^{1}$ Clinical Laboratory, Faculty of Veterinary Medicine, Universitas Syiah Kuala, Banda Aceh, Indonesia \\ ${ }^{2}$ Study Program of Veterinary Medicine, Faculty of Veterinary Medicine, Universitas Syiah Kuala, Banda Aceh, Indonesia \\ ${ }^{3}$ Physiology Laboratory, Faculty of Veterinary Medicine, Universitas Syiah Kuala, Banda Aceh, Indonesia \\ ${ }^{4}$ Reproduction Laboratory, Faculty of Veterinary Medicine, Universitas Syiah Kuala, Banda Aceh, Indonesia
}

\begin{abstract}
This study aimed to compare estrous performance and progesterone concentration during the estrous cycle of kacang goats induced by PGF $2 \alpha$ versus ovsynch protocol. This research used six female kacang goats. The goats were divided into two groups namely the K1 group which was induced by injecting $7.5 \mathrm{mg}$ PGF $2 \alpha$ intramuscularly in 10 days interval and $\mathrm{K} 2$ group which was induced by using the ovsynch method. Protocol for K2 group was as follow; at day 1, the goats were injected with $7.5 \mathrm{mg} \mathrm{PGF} 2 \alpha$; at day 8, they were injected with $50 \mu \mathrm{g} \mathrm{GnRH}$; at day 15 they were injected with $7.5 \mathrm{mg}$ PGF2 $\alpha$; at day 18 they were injected with $50 \mu \mathrm{g}$ GnRH. Estrous were detected using male goat and visual observation. The blood samples were taken on days 7, 14, and 21 after estrous. Progesterone concentration was measured with enzyme-linked immunosorbent assay (ELISA) technique. Intensity, onset, and duration of estrous in K1 group versus $\mathrm{K} 2$ group were $8.33 \pm 2.08$ vs $7.00 \pm 1.00 ; 56.00 \pm 34.12$ vs $36.00 \pm 20.78$ hours; and $24.00 \pm 26.15$ vs $24.00 \pm 20.78$ hours, respectively ( $\mathrm{P}>0.05$ ). Level of progesterone hormone on day 7, 14, and 21 for $\mathrm{K} 1 \mathrm{vs}$ K2 were $0.812 \pm 0.710$ vs $2.369 \pm 3.351 ; 5.051 \pm 7.754$ vs $3.091 \pm 4.385 \mathrm{ng} / \mathrm{ml}$; and $4.173 \pm 6.692$ vs $3.562 \pm 4.113 \mathrm{ng} / \mathrm{mL}$, respectively $(\mathrm{P}>0,05)$. It can be concluded that the differences in synchronization protocols between PGF2 $\alpha$ versus ovsynch do not affect the performance of estrous and the concentration of progesterone during the estrous cycle of kacang goats.
\end{abstract}

Keywords: ovsynch, PGF2 $\alpha$, kacang goats, progesterone, estrous performance.

\section{Introduction}

The goat population in Aceh Province until 2016 reached 623,038 with a growth rate of around $3.14 \%$ (http://disnak.acehprov.go.id/). This low growth rate was caused by low estrous expression in goats and inadequate estrous detection technique, therefore mating time could not be predicted and conducted punctually. In an account of the issue, marriage control applications are needed to improve production, fertility, and fecundity [1].

One of the efforts to improve the efficiency of goat reproduction is by implementing estrous synchronization technology. Synchronization is generally done using prostaglandin F2 alpha (PGF2 $\alpha$ ) hormone or progesterone which are intended to manipulate goat hormone, therefore progesterone level would decrease to the lowest level [2]. Decreased progesterone will cause estrogen secretion from dominant follicle cells which stimulate the onset of estrous symptoms. The PGF $2 \alpha$ hormone is the most commonly used hormone to induce estrous because it has luteolytic nature, could lyse/rejuvenates the corpus luteum, causes an increase in blood progesterone, increases ovarian follicle development, and stimulates ovulation within 2-6 days after injection [3].

One protocol that is currently popularly used to synchronize the estrous period is ovsynch. The ovsynch method helps ensure ovulation occurs within a period, produces good fertility, and does not require estrous detection. The ovsynch protocol uses a combination of gonadotrophin-releasing hormone $(\mathrm{GnRH})$ and PGF2 $\alpha$. In cows, the implementation of the ovsynch protocol is carried out by injection of GnRH on day 0 which attempts to induce follicular ovulation and start a new follicular wave. On the $7^{\text {th }}$ day, cows are injected with PGF $2 \alpha$ to rejuvenate the corpus luteum. On day 9, cows are injected with a second GnRH which induces ovulation in dominant follicles recruited after the first $\mathrm{GnRH}$ injection. Artificial insemination is carried out 12-16 hours after the second injection of GnRH [5]. The ovsynch protocol has been carried out on Saanen goats [6], Malabari Cross-Bred Goats [7], and Indian goats [1], but no one has used this protocol in Kacang Goat.

\footnotetext{
Corresponding author: siregar@unsyiah.ac.id
} 


\section{Materials and Methods}

This study used six female Kacang goats which were 2-3 years old, clinically healthy, and had two regular cycles. The samples were divided into two groups which consisted of three goats. The first group (K1) underwent estrous synchronization using the PGF $2 \alpha$ method, while the second group (K2) underwent ovsynch method.

\subsection{Research procedure}

\subsubsection{Estrous synchronization and mating}

K1 group was induced by $7.5 \mathrm{mg}$ PGF2 $\alpha$ (Lutalyse TM, Pfizer, Belgium) intramuscularly in two injections at tenday intervals. K2 group was induced by ovsynch method. The ovsynch protocol was started on day 1 with an injection of $7.5 \mathrm{mg}$ PGF2 $\alpha$. On the 8th day, the goats were injected with $50 \mu \mathrm{g}$ GnRH (Fertagyl TM, Intervet, Netherland) and on the 15th day, they were injected with $7.5 \mathrm{mg}$ PGF2 $\alpha$. On the 18th day, the goats were injected with $50 \mu \mathrm{g}$ GnRH [8] Simoes, 2016). Observation of estrous was carried out three times a day at $6 \mathrm{am}, 12 \mathrm{am}$, and $6 \mathrm{pm}$ visually and using male cattle assistance in four days after the last PGF2 $\alpha$ injection.

\subsubsection{Estrous Intensity Scoring}

Estrous response visualization consisted of silent behavior when a male cow rode the cow, redness of the vulvar mucosa, vulvar swelling, and scoring of mucus viscosity. The male cow rode the female cow, a score of 3 was given when the female remained silent, a score of 2 when the female was in doubt and a score of 1 when the female showed no reaction. A score of 3 was given for red mucosa, 2 for pink mucosa, and 1 for pale pink mucosa. A score of 3 was given for large vulvar swelling (twice normal size), 2 for slight swelling, and 1 if the vulva does not experience swelling. A score of 3 was given when if the mucus secret was viscous, clear, and hanging or soaking around the vulva, a score of 2 when the amount of the mucus was small, and a score of 1 when there was no secret [9]. The score was taken from the highest intensity score at the time of observation.

\subsubsection{Blood Sampling}

Blood samples were taken on the $7^{\text {th }}, 14^{\text {th }}$, and $21^{\text {st }}$ days of the estrous cycle. The blood for measurement of hormonal concentrations was taken from the jugular vein of Kacang goat using a $5 \mathrm{ml}$ disposable syringe. The blood was put in a microtube and placed in an ice flask. The blood was then taken to the Research Laboratory for serum extraction. The centrifuge was carried out at 2,500 rpm for 15 minutes. The serum was then taken from the tube with a micropipette and inserted into a microtube. The serum was stored in a freezer of $-20^{\circ} \mathrm{C}$ until the time it was used for hormonal analysis. Measurement of progesterone concentration was carried out by the ELISA method using progesterone kit (Cat No. 1562, DRG Instrument GmbH Germany).

\subsubsection{Measurement of progesterone concentration}

In each ELISA microplate, $25 \mu 1$ standard solution was poured and then sample and control were added. $200 \mu 1$ of progesterone conjugate reagent was added to each microplate. The microplate was incubated for 60 minutes at room temperature. The solution was rinsed three times by adding $300 \mu \mathrm{l}$ washing solution to each microplate. Furthermore, each microplate was put into $200 \mu \mathrm{l}$ of substrate solution and incubated for 20 minutes at room temperature. The enzymatic reaction was stopped by adding $100 \mu \mathrm{l}$ stop solution to each microplate. The absorbance value was read on the ELISA reader before 10 minutes after the addition of stop solution using an absorbance wave of $450 \pm 10 \mathrm{~nm}$.

\subsection{Data analysis}

The estrous performance data including the intensity and duration of estrous and progesterone level were analyzed using the T-test with the help of SPSS (Statistical Product and Service Solutions) software program.

\section{Results and Discussion}

In this study, all goats (100.0\%) who received ovsynch treatment showed symptoms of estrous, whereas, in the PGF $2 \alpha$ estrous induction protocol, there was only $66.7 \%$ (Table 1). The relatively similar results were also reported by Pujar et al. [1] in Indian goats (99.16\%) and Holtz et al. [10] in Boer goats (100.0\%). The slightly different result was reported by Panicker et al. [7] which obtained an estrous percentage of $75.0 \%$ in Malabari crossbreed goats that were induced with ovsynch protocol.

Table 1. Comparison of estrous performance and progesterone levels of induced Kacang Goat with PGF2 $\alpha$ vs ovsynch protocol

\begin{tabular}{lcc}
\hline \multirow{1}{*}{ Variable } & \multicolumn{2}{c}{ Treatment Protocol } \\
\cline { 2 - 3 } & PGF2 $\alpha$ & Ovsynch \\
\hline Number of goats & 3 & 3 \\
Estrous Percentage & $2(66.7 \%)$ & $3(100.0 \%)$ \\
$\begin{array}{l}\text { Estrous: } \\
\text { Intensity }\end{array}$ & $8.88 \pm 2.08$ & $7.00 \pm 1.0$ \\
$\begin{array}{l}\text { Duration (hour) } \\
\text { Progesterone Level }\end{array}$ & $24.00 \pm 26.15$ & $24.00 \pm 20.78$ \\
(ng/mL): & & \\
Day-7 after estrous & $0.812 \pm 0.710$ & $3.091 \pm 4.385$ \\
Day-14 after estrous & $2.369 \pm 3.351$ & $4.173 \pm 6.692$ \\
Day-21 after estrous & $5.051 \pm 7.754$ & $3.562 \pm 4.113$ \\
\hline
\end{tabular}

In this study, the Kacang goat showed an unfavorable response to the implementation of estrous synchronization with PGF2 $\alpha$. Santoso et al. [9] reported better results of $95.0 \%$ using the same dose. This difference is most likely due to differences in the administration and dose of PGF $2 \alpha$. The increase in the percentage of estrous in Simoes [8] study occurred when the 12-day interval was used and the percentage was increased to $100.0 \%$ in day 10 when the dose was increased to $37.5 \mathrm{mg}$. Goats that did not show estrous in 
this study might experience silent estrous. This is related to the low level of estrogen released into the bloodstream so that the intensity of estrous is not adequate.

The intensity of estrous obtained in Kacang goat induced by PGF $2 \alpha$ and ovsynch was $8.33 \pm 2.08$ and $7.00 \pm 1.00(\mathrm{P}>0.05)$, respectively. Panicker et al. [7] also acquire an inadequate intensity score on the Malabari cross-breed goat induced by ovsynch with a score of $13.74 \pm 1.57$ using a 0 to 20 estrous scaling scale. The Kacang goat induced by PGF $2 \alpha$ in this study has a relatively higher estrous intensity because some goats have a score of 3 . Yendraliza [11] stated that inadequate energy is possibly the biggest cause of reproductive disorders in livestock. Feradis [12] added that the level of food affects the synthesis and release of hormones from the endocrine glands, therefore nutritional status in cattle could influence follicular development and ovulation capacity.

Duration of estrous in Kacang goat induced with PGF $2 \alpha$ and ovsynch were $24.00 \pm 26.15$ and $24.00 \pm$ 20.78 hours $(\mathrm{P}>0.05)$, respectively. Estrous duration in goats varies from 8 to 32 hours [13]. Longer estrous duration $38.00 \pm 5.0$ hours was reported by [1] in Indian goats induced by ovsynch. Nur et al. [6] reported the duration of estrous in Saanen goats induced by the cosynch and ovsynch protocols was 34.4 and 29.4 hours respectively. The duration of estrous in Malabari crossbred goats induced with ovsynch protocol was $35.05 \pm$ 4.79 hours [7].

In general, the duration of estrous in this study was relatively shorter compared to other reports. This difference could be due to differences in estrous observation patterns. In this study, estrous observations were carried out three times per day while in other studies the exact number of observations made in each day was not reported. Suharyati [14] found that the duration of estrous was largely influenced by several factors such as nation, age, and season. Adams et al.[15] stated that nutritional deficiencies could result in low estradiol secretion. According to Hadjopranjoto [16], the lack of nutrition would decrease the function of all glands in the body. One of the targeted glands was the anterior pituitary gland followed by decreased gonadotropin hormone secretion namely FSH and $\mathrm{LH}$ which are responsible for the process of folliculogenesis and ovulation.

The concentration of progesterone in Kacang goat during the estrous cycle on days 7, 14, and 21 after induction are presented in Table 1. It can be seen that the concentration of progesterone in the estrous cycle of the $\mathrm{K} 1$ group on days 7, 14, and 21 was $0.812 ; 2,369$; and $5,051 \mathrm{ng} / \mathrm{ml}$, respectively, while in K2 group were 3.091; 4.173; and $3.562 \mathrm{ng} / \mathrm{ml}$. Based on these results, it could be seen that the concentration of progesterone in each group was fluctuating. According to Budi [17], the rise and fall of progesterone concentration is an interpretation of ovarian activity, namely the formation or regression of the corpus luteum.

Concentrations of progesterone in the $\mathrm{K} 1$ group on days 7,14 , and 21 showed no significant difference $(\mathrm{P}>$ 0.05 ) although it tended to increase on day 14. This result is in line with a study by [18] which found that on days 7 and 14 of kacang goat estrous cycle, there would be an increase in progesterone concentration because the luteal phase occurred on day 7 to 16 . When corpus luteum is active, progesterone secretion increases. The highest concentration of progesterone in this study was seen on day 21 even though the goat did not experience pregnancy. This was possibly due to shorter estrous cycle, therefore on that day, the goat had entered the luteal phase again. Progesterone concentration was continuously increased, possibly due to the more mature corpus luteum that was produced by fertilization. An increase in progesterone concentration in this phase is needed to help the process of implantation of the embryo in the uterine wall and fetal maintenance during the pregnancy [19, 20, 21].

Concentrations of progesterone in the $\mathrm{K} 2$ group on days 7,14 , and 21 showed no significant difference $(\mathrm{P}>$ 0.05). This probably happened because the corpus luteum was not functioning optimally. Jaenudeen and Hafez [22] stated that a low concentration of progesterone could be caused by cattle which experience ovarian dysfunction. Reproductive disorders in the form of ovarian malfunction caused by factors such as the change of seasons, nutritional deficiencies, stress due to lactation, and aging [23].

In each period of blood collection, there was no difference between $\mathrm{K} 1$ and $\mathrm{K} 2$ treatments $(\mathrm{P}>0.05)$ although there was a tendency that the concentration of progesterone in $\mathrm{K} 1$ was greater than K2. This was different from the previous report by Mee, Ryan, and Condon [24] which found that cow which was injected with GnRH during the estrous cycle had greater progesterone concentration after ovulation for 40 days after GnRH administration. The cow could maintain pregnancy because of the increased ratio of theca cells in the corpus luteum.

The increase in progesterone occurs due to the increased number of corpus luteum produced in superovulated mother to mother which were not superovulated, both in mother with single offspring or twin offspring [25]. With more and more mature lutein cells in the corpus luteum, the activity of progesterone synthesis and progesterone secretion increases. The corpus luteum in goats is the main organ that produces progesterone [26-27].

According to Arimbawa, Trilaksana, and Pemayun [28], increases and decreases in progesterone levels are in line with the development of the corpus luteum during the estrous cycle. The tendency for differences in age and individual livestock also influences hormone production [29]. The differences in hormone production could be caused by differences in hormone preparations and doses given, patterns of observation factors, conditions of livestock, and food provision [30].

\section{Conclusion}

It can be concluded that the differences in synchronization protocols between PGF2 $\alpha$ versus ovsynch do not affect the performance of estrous and the 
concentration of progesterone during the estrous cycle of kacang goats.

\section{References}

1. Pujar C, Puro NA, Markandeya NM, et al.: Studies on the efficacy of select synch and ovsynch protocols for induction and synchronization of estrus in Osmanabadi goats. Int J Sci Technol. 2016; 5(6):40694073.

2. Macmillan KL, Segwagwe BV, Pino CS: Association between the manipulation of patterns follicular development and fertility in cattle. Anim. Reprod. J. Sci. 2003; 78:327-344.

3. Brito LFC, Satrapa R, Marson EP, et al: : Efficacy of PGF2 $\alpha$ to synchronize estrus in water buffalo cows (Bubalus bubalis) is dependent upon plasma progesterone concentration, corpus luteum size, and ovarian follicular status before treatment. Anim. Reprod. Sci. 2002; 73:23-35

4. Taponen J: Fixed-time artificial insemination in beef cattle. Acta Vet. Scand. 2009; 51(48):16.

5. Pursley JR, Kosorok MW, Wiltbank MC: Reproductive management of lactating dairy cows using synchronization of ovulation. J. Dairy Sci. 1997; 80:301-306.

6. Nur Z, Nak Y, Nak D, et al.: The use of progesteronesupplemented Co-synch and Ovsynch for estrus synchronization and fixed-time insemination in nulliparous Saanen goat. Turk J Vet Anim Sci 2013; 37: 183-18815.

7. Panicker SS, Kanjirakuzhiyil $\mathrm{P}$, Koodathil R, et al. : Oestrus response and conception rate in malabari crossbred goats following two different oestrus synchronization protocols. J Anim Health Prod. 2015; 3(2): 398

8. Simoes J: Synchronization of ovulation in goats using prostaglandin $F 2 \alpha$ based protocols during the breeding season. J. Coastal Life $\quad$ Med. 2016; 4(3):240-243.

9. Santoso, Amrozi P, Bambang, et al.: Gambaran ultra sonografi ovarium kambing kacang yang disinkronisasi dengan hormone prostaglandin f2 alfa (PGF2 a) dosis tunggal. J. Ked. Hewan. 2014; 8(1): 3842.

10. Holtz W, Sohnrey B, Gerland M, et al. : Ovsynch synchronization and fixed time insemination in goats. Theriogenology. 2008 ; 69: 785-792

11. Yendraliza: Pengaruh nutrisi dalam pengelolaan reproduksi ternak. Kutubkhanah 2013; 16 (1):20-26.

12. Feradis, MP: Reproduksi Ternak. Penerbit Alfabveta. Bandung. 2010.

13. Hafizuddin, Sari WN, Siregar TN, et al. : Persentase berahi dan kebuntingan kambing peranakan etawah (PE) setelah pemberian beberapa hormon prostaglandin komersial. J. Ked. Hewan. 2011; 5(2):8488.

14. Suharyati S: Pengaruh pemberian PMSG dan hCG terhadap kinerja reproduksi kambing peranakan Ettawah yang disinkronisasi estrus dengan progesteron. Tesis. Program Pascasarjana, Universitas Gadjah Mada. Yogyakarta. 1999
15. Adams NR, Abordi JA, Briegel JR, et al.: Effect of diet on the clearance of estradiol-17-beta in the ewe. J. Biol. Reprod. 1994;5:668-674.

16. Hadjopranjoto S: Ilmu Kemajiran pada Ternak. Airlangga University Press. Surabaya. 1995.

17. Budi WD: Peran kadar progesteron dalam plasma darah untuk deteksi estrus dan aktivitas ovarium. Seminar Nasional Peternakan dan Veteriner. 1998; 268269.

18. Siregar TN: Fisiologi Reproduksi pada Hewan Betina. Universitas Syiah Kuala. Banda Aceh. 2006

19. McDonald LE: Veterinary Endocrinology and Reproduction. $3^{\text {th }}$ ed. Lea\& Febiger. Philadelphia. 1980.

20. Stabendfelt GH, Edqvist L: Female Reproductive in Dikes.Physiology of Domestic Animal. $11^{\text {th }}$ ed. M.J. Swenson \&W.O. Reece. Comstock Publ. ASS Cornel Univ London. 1993.

21. Manalu W, Sumaryadi MY, Kusumorini N: Effect of fetal number on the concentrations of circulating maternal serum progesterone and estradiol of does during late pregnancy. Small Rumin Res. 1996; 23:117-124.

22. Jaenudeen MR, Hafez ESE: Cattle and Buffalo in Reproduction In Farm Animal. $7^{\text {th }}$ Ed. Edited by Hafez ESE. Lippincott Williams \& Wilkins. Maryland. USA. 2000.

23. Gracia M, Perera O, Goodger WJ, et al. : User Manual for Artificial Insemination Database Application (AIDA), Version 3.3, Animal Production and Health Section. Joint FAO/IAEA Division. Vienna. Austria. 1996.

24. Mee JF, Ryan DP,Condon T: Ultrasound diagnosis of pregnancy in cattle. Vet Rec. 1994; 134:532-539.

25. Adriani, Sudono A, Sutardi T, et al. : Pertumbuhan prenatal dalam kandungan kambing melalui superovulasi. Animal Production. 2007; 14:44-48.

26. Nalbandov AV: Reproductive Physiology of Mammals and Birds. W.H. Freeman \& Company. San Francisco. 1976

27. Reeves JJ: Endocrinology of reproduction. In: Hafez ESE (ed). Reproduction in Farm Animals. $5^{\text {th }}$ ed. Lea \& Febiger. Philadelphia. 1987.

28. Arimbawa IWP, Trilaksana IGNB, Pemayun TGO: Gambaran hormon progesteron sapi bali selama satu siklus estrus. Indonesia Medicus Veterinus. 2012; 1(3):330-336.

29. Siregar TN, Hartantyo S, Sugijanto: Induksi ovulasi kambing kacang prepuber dengan PMSG dan hCG. Agrosains. 1999; 12(1):35-48.

30. Toelihere MR: Fisiologi Reproduksi pada Ternak. Angkasa. Bandung. 2003. 